\title{
СТАЛИЙ РОЗВИТОК МІСТ ТА РЕГІОНІВ: ПРОБЛЕМИ ДОСТУПНОСТІ ЯКІСНИХ ПОСЛУГ З ПОСТАЧАННЯ БЕЗПЕЧНОЇ ПИТНОЇ ВОДИ
}

\author{
I.C. Сагайдак, Т.М. Чорна, В.I. Павлішина \\ Університет державної фіскальної служби України \\ вул. Університетська, 32, Ірпінь, 08200, Україна \\ e-mail: mykroskop@gmail.com; chornayat@i.ua; vika.pavlishina@gmail.com
}

Актуальність теми. Роль системи водопостачання та водовідведення важко переоцінити, оскільки вона є однією з основних у забезпеченні доброту населення, має значний вплив на інші галузі національного господарства України та розвиток регіональних економік.

Але, на жаль, їі стан із року в рік характеризується такими критеріями як незадовільний технічний стан водопровідних та каналізаційних мереж, споруд, обладнання; дефіцит фінансових ресурсів, необхідних для належної експлуатації, обслуговування та модернізації систем водопостачання/водовідведення; недосконалість структури управління галуззю та нормативно-правової бази для забезпечення ії̈ надійного та ефективного функціонування [1, 2]. Все це безумовно впливає на забезпечення якісною та безпечною для здоров'я населення питною водою.

Метою роботи $є$ аналіз взаємозв'язків між якістю питної води та сучасним станом системи водопостачання в Україні.

Інклюзивний процес адаптації Цілей сталого розвитку (ЦСР), проголошених в резолюції Генеральної Асамблеї ООН у вересні 2015 р., з урахуванням специфіки національного розвитку України, викладено у Національній доповіді «Цілі сталого розвитку: Україна». Серед 17 Цілей, ЦСР 6 охоплює забезпечення наявності та сталого управління водними ресурсами та санітарією, завданнями для здійснення якої передбачено [3]: забезпечення доступності якісних послуг з постачання безпечної питної води, будівництво та реконструкцію систем централізованого питного водопостачання із застосуванням новітніх технологій та обладнання; забезпечення доступності сучасних систем водовідведення, будівництво та реконструкція водозабірних та каналізаційних очисних споруд із застосуванням новітніх технологій та обладнання; зменшення обсягів скидання неочищених стічних вод, у першу чергу 3 використанням інноваційних технологій водоочищення, на державному та індивідуальному рівнях; підвищення ефективності водокористування; забезпечення впровадження інтегрованого управління водними ресурсами.

За даними [4], доступ до централізованого водопостачання має 26 \% сільського і 89,5\% міського населення країни; 3,4 \% сільського населення має доступ до централізованого водовідведення і 77 \% міського населення.

В сучасних умовах для багатьох територіальних громад як сам стан системи централізованого водопостачання/водовідведення, так і забезпечення населення послугами належного рівня в зазначеній сфері $є$ справжнім викликом. Насамперед, це пов'язано 3 
незадовільною якістю питної води, що надходить до споживача. Основними причинами ситуації, що склалася у сфері питного водопостачання, є наступні.

1) Суттєве погіршення стану джерел водопостачання. Джерелами води для систем централізованого водопостачання в Україні є поверхневі водні об'єкти і запаси підземних вод. Підземні джерела водопостачання за період їх експлуатації (здебільшого 35-40 років) суттєво погіршили свою якість і сьогодні лише 57 \% 3 них відповідають вимогам джерел 1-го класу згідно ДСТУ 4808:2007, 36 \% - вимогам 2-го класу, а решта 7 \% - 3-го класу [5]. Ще гірше виглядає ситуація 3 поверхневими джерелами водопостачання: жодне 3 них не відповідає сьогодні вимогам 1-го класу [6]. А отже, наразі, для доведення води до нормативних вимог необхідно впроваджувати відповідні додаткові заходи (використовувати нові реагенти, змінювати технологію водоочищення), що в свою чергу потребує додаткового фінансування.

2) Критичний технічний стан водогонів і розподільчих мереж, що підтверджується наступними статистичними даними [7]:

- станом на 01.01.2020 р. сумарна протяжність водопровідних мереж в Україні складала 120,321 тис. км, серед яких 38,3 \% у зношеному та аварійному стані; замінено було лише 2,3\% від потреби, а показник аварійності (кількість аварій на 1 км водопровідних труб) складав від 0,24 до 25,3 .

- сумарна протяжність каналізаційних мереж - 39,351 тис. км, 3 яких 40,9 \% в аварійному стані, а протягом 2019 р. було замінено лише 1,2 \% від потреби; показник аварійності складав від 0,04 до 97,4.

Із загальної кількості водопровідних мереж переважна більшість (47 \%) прокладена із чавунних труб, 41 \% - із сталевих, труб без внутрішньої ізоляції, що і призводить до високої аварійності та спричиняє забруднення питної води; 5 \% водогонів, що прокладені із азбоцементних труб; 3 \% - полівінілхлоридних і поліетиленових та 2 \% залізобетонних труб $[7,8]$.

3) Фінансові проблеми галузі. Окрім нестачі коштів для своєчасної заміни зношеного обладнання та приведення його у відповідність до гідравлічних потреб системи, характерним $\epsilon$ великі втрати води в системі водопостачання. За останні 15 років спостерігається стійка тенденція до зменшення обсягів водоспоживання ( на $35 \%)$, в першу чергу за рахунок зменшення водоспоживання промисловими підприємствами. Натомість відбувається збільшення втрат води (з $16 \%$ до $45 \%$, а інколи й більше) [9]. Так, у 2019 р. ці втрати склали 34,9 \%. Половина втрат - наслідок хронічних неплатежів [10].

Втрати води призводять до зайвого енергоспоживання. До того ж, ситуація ускладнилася після того, як з 01.06.2019 р. повноцінно запрацювала нова модель ринку електроенергії, в результаті чого відбулось подорожчання електроенергії для підприємств на 25 \%. Нові правила передбачають, що усі підприємства мають надавати передплату за електроенергію. Водоканали не знаходяться у державній власності, а належать містам. Щоб не допустити припинення роботи водоканалів, міська влада дотує підприємства з місцевих бюджетів. Але робити це постійно просто неможливо. Збиток галузі на кінець 2019 р. перевищив 6,5 млрд. грн. (близько $2 \%$ ВВП).

На підтримку галузі у 2011 р. прийнято Загальнодержавну цільову програму «Питна вода України» на 2011-2020 роки, відповідно якій було передбачено фінансування на суму біля 3 млрд. грн. за рахунок Державного бюджету. На жаль, за всі попередні роки було виділено лише 208 млн грн. [11]. Тоді як, за підрахунками експертів, сума коштів, яка потрібна для реконструкції підприємств водопостачання та водовідведення України становить близько 40 млрд доларів [12]. 
3 активізацією процесів децентралізації об’єднані територіальні громади (ОТГ) мають можливість планувати і реалізовувати програми з модернізації, оптимізації та розвитку систем водопостачання та водовідведення. Розглянемо, наскільки вдалими можуть бути такі процеси, на прикладі Ірпінського регіону.

Система водопостачання та водовідведення м. Ірпінь від початку формувалася в розрахунку на курортне містечко $\mathrm{i}$, для забезпечення населення водою вистачало десяти свердловин. Але останніми роками регіон розбудовується шаленими темпами (за минулі 4-5 років збудовано понад 1 млн $\mathrm{m}^{2}$ житла). Водопостачання в місті практично повністю здійснюється через центральний водогін, навіть у приватних садибах.

Комунальне підприємство (КП) «Ірпіньводоканал» забезпечує питною водою населення, комунально-побутові та промислові підприємства м. Ірпінь, м. Буча, смт Гостомель та смт Ворзель; здійснює експлуатацію об'єктів і споруд водопровідних мереж і мереж каналізаційних колекторів; відводить каналізаційні стоки; контролюе якість питної води і здійснює контроль використання каналізаційних лімітів водоспоживання й водовідведення. Його послугами користуються 60261 населення (включаючи вищезгадані сусідні населені пункти), 1286 підприємств різних форм власності, в т. ч. 55 бюджетних організацій [13].

Ірпінський регіон користується на $100 \%$ підземними водами Бучакського та Сіноманського горизонтів. В основному використовується більш потужний Бучакський горизонт (глибина 60-80 м) з високим вмістом заліза. Сіноманський (глибина 100-120 м) менш потужний, до того ж містить сірководень, що надає воді неприємного запаху.

На модернізацію системи водозабезпечення і водовідведення в Приірпінні впродовж 20162018 рр. було виділено 141 млн грн. (рис.1) на: реконструкцію та будівництво свердловин, будівництво станцій водопідготовки та знезалізнення води (3 станції в Бучі, Ворзелі, Гостомелі), придбання нової техніки і обладнання, ремонт водопровідної мережі та каналізаційних колекторів. В Ірпені замінили понад 60 \% старих мереж, у Бучі більше половини. Але нарікання на якість води все ж тривають. Проблема в тому, що частина мереж - це трубопровід, який прокладали з чавунних труб діаметром 100 мм. Крім того існують тупикові мережі, де вода застоюється [11].

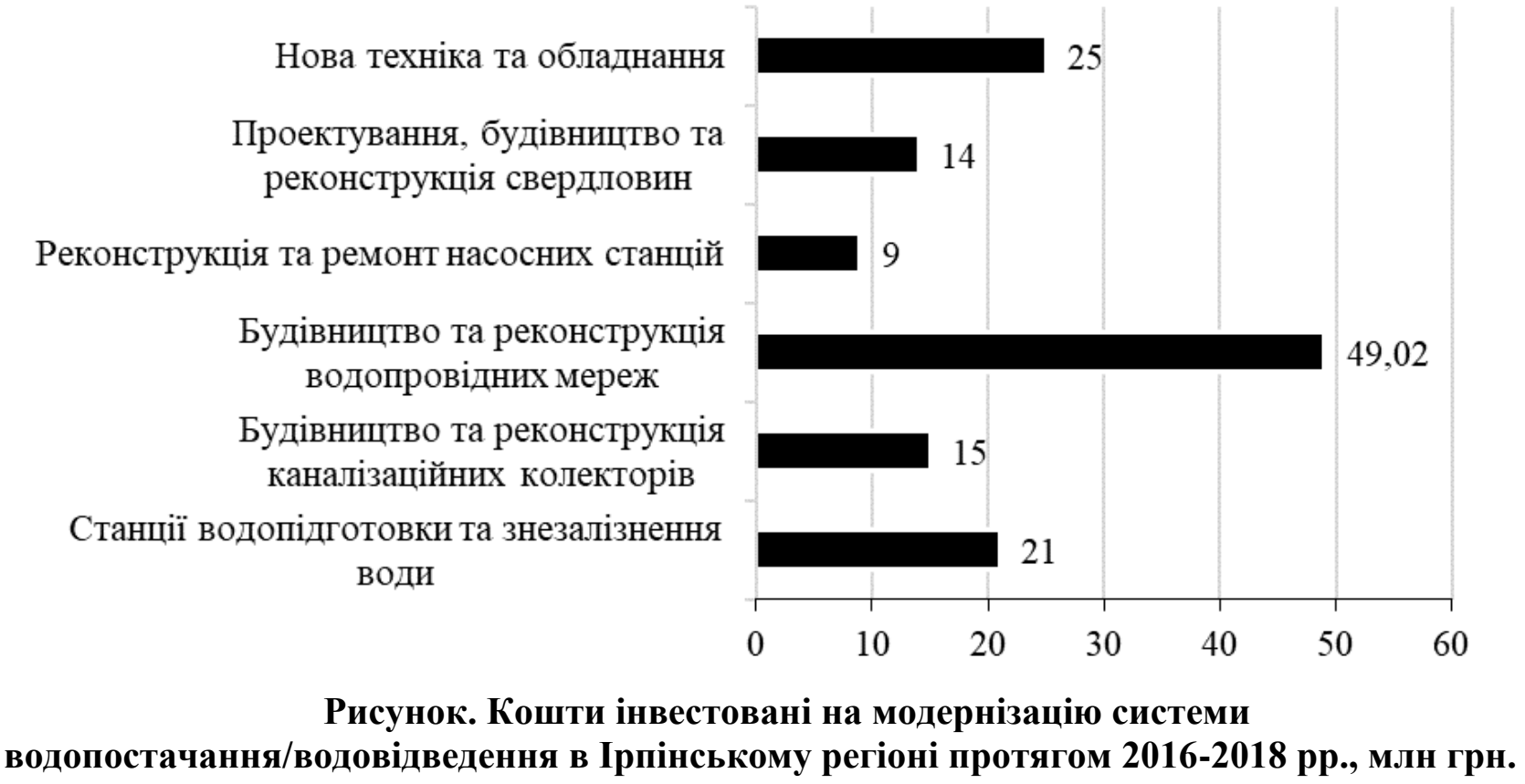

Handbook of the XXII International Science Conference 
Наразі КП «Ірпіньводоканал» - одне 3 найкращих підприємств галузі в Україні: підприємству вдалося побороти проблему незаконних підключень, майже скрізь встановлено лічильники 3 можливістю передачі даних в режимі онлайн. Але потрібні системні дослідження, чи вистачить води для подальшого зростання міста. Вже зараз можна говорити про дефіцит земельних ділянок для нових свердловин, які необхідно розміщувати на певній відстані одна від одної. Так, якщо ще кілька років тому у Ірпені щороку вводилося в дію 4-6 нових свердловин, то зараз - лише 2-3. Вже зараз необхідно проводити додаткові розвідки водоносних горизонтів. Водночас варто проаналізувати i плани забудови - чи відповідають видані технічні умови перспективним можливостям водоканалу, чи не доведеться місту зробити вимушену «паузу» у розвитку через нестачу води у найближчому майбутньому [14].

Що стосується системи водовідведення, то наразі стоки 3 Ірпеня надходять до каналізаційної системи Києва, яка поки що дає змогу забезпечити якісні комунальні послуги та стабільну екологічну ситуацію. Місто платить чималі кошти, і якою буде політика Київводоканалу щодо передмістя в майбутньому - невідомо. Тому Ірпеню доречно вивчити питання щодо спорудження власних потужностей з очищення стічних вод. Сучасні технології дозволяють зробити такі об’єкти досить екологічними, але знову ж таки - це питання землі і коштів.

Висновки. Таким чином, однією з пріоритетних складових розбудови сучасного міста і забезпечення комфортного проживання в ньому виступає комплексна програма розвитку системи водопостачання і водовідведення.

\section{Література:}

1. Сагайдак I.C., Павлішина В.I. Значення системи водопостачання та водовідведення у розвитку інфраструктури Ірпінського регіону: Збірник тез доповідей міжнародної науково-практичної Інтернет-конференції «Забезпечення сталого розвитку міст та регіонів: стан в Україні та зарубіжний досвід» 25 лютого 2021 року: Університет державної фіскальної служби України, 2021. - С. 221-224.

2. Чорна Т.М., Гусятинська Н.А. Екологічні та економічні аспекти питного водопостачання в Україні. Матеріали Міжнародного конгресу «ЕТЕВК-2019», 10-14 квітня 2019. - Чорноморськ, 2019. - С. 78-90.

3. Цілі Сталого Розвитку: Україна: Національна доповідь. 2017. URL: http://un.org.ua/images/SDGs_NationalReportUA_Web_1.pdf 
4. Цілі Сталого Розвитку Україна - 2020: Моніторинговий звіт. 2020. URL: https://www.unicef.org/ukraine/reports/sustainable-development-goals-ukraine-2020monitoring-report

5. Джерела централізованого питного водопостачання. Гігієнічні та екологічні вимоги щодо якості води і правила вибирання: ДСТУ 4808:2007.

6. Гіпп Т.Р. Технічний стан систем централізованого водопостачання та водовідведення. - Офіційний веб-сайт Українського центру водних проблем. URL: https://cleanwater.org.ua/tehnichnyj-stan-system-tsentralizovanoho-vodopostachannya-tavodovidvedennya/

7. Національна доповідь про якість питної води та стан питного водопостачання в Україні у 2019 році. URL: https://www.minregion.gov.ua/wp-content/uploads/2020/11/proektnacz.-dop.-za-2019.pdf

8. Федулова С.О. Економіка підприємств водопостачання та водовідведення: навч. посіб. / С.О. Федулова; за ред. О.А. Півоварова. Дніпро : ДВНЗ УДХТУ, 2017. 300 с.

9. Кравченко О.В. Аналіз та оцінка стану питного водопостачання / О.В. Кравченко, В.Г. Каніболоцький, О.С. Панченко // Газета «Погляд». - №23 від 25.05.2018 р.

10. Все про воду в Ірпені. ЗНАЮ. 2019. №2. URL: https://www.04597.com.ua/news/2340203/vse-pro-vodu-v-irpeni-citajte-v-novomu-vipuskugazeti-znau

11. Крилова I.I. Аналіз сучасного стану сфери водопостачання та водовідведення в Україні. Інвестиції: практика та досвід. 2018. № 23. С. 118-125.

12. Корніловська Н. 3 проекту бюджету на 2019 рік виключили кошти на підтримку програми водопостачання. URL: https://ukrvodokanal.in.ua/ (дата звернення: 10.10.2019).

13. Офіційний веб-сайт КП «Ірпіньводоканал». URL: http:/vodokanal-irpen.com.ua/

14. Карпенко О. Город построен, а воды нет, или Почему ирпенская вода нуждается в системных решения. Украинская правда. URL: https://www.pravda.com.ua/rus/columns/2020/10/22/7270772/ 22 